\title{
Implementation of the Performance Accountability System for Government Agencies (SAKIP) in Realizing Good Governance at the Kediri City Health Office
}

\author{
Muhammad Rizal \\ Universitas Islam Kadiri, Indonesia \\ Corresponding author email: dr.rizalamin@gmail.com \\ Eka Askafi \\ Universitas Islam Kadiri, Indonesia \\ Email: eka_askafi@uniska-kediri.ac.id \\ Supriyono \\ Universitas Islam Kadiri, Indonesia \\ Email: supriyono@uniska-kediri.ac.id
}

\begin{abstract}
In the implementation of SAKIP at the Kediri City Health Office, there were obstacles in making reports and implementing policies. This study used a qualitative descriptive method with a purposive sampling method. The result is a determinant of decision or policy-making by looking at the existing problems to produce an accurate strategy to improve performance. The priority scale of the program that is carried out then becomes very important in the sustainability of SAKIP in the coming year. This study is based on the results or performance orientation shown in the Government Agency Performance Report (LKjIP) and the implementation of SAKIP itself. The purpose of this research is to identify problems and solutions to problems faced in governance. Agency Performance Accountability System.

Keywords---good governance, health office, kediri city, SAKIP.
\end{abstract}

\section{Introduction}

According to the 2019 UN Human Development Index report, Indonesia has a 111 the quality of life ranking out of 189 countries. The annual Human Development Index ranking is calculated using three categories: health, education, and income. Quoted from the 2019 Human Development Index Ranking website, Indonesia shares a place in the 111th place with Samoa. Indonesia's life expectancy is 71.5 years while Samoa's is 73.2 years. Hong Kong has the highest life expectancy at 85 years old, while the Central African Republic has the lowest life expectancy at 52.8 years. Indonesia's per capita gross national income figure is around US $\$ 11,256$ or Rp 157 million per head. Moreover, the average Indonesian school year is eight years, with the expected school year at 12.9 years. The Human Development Index (HDI) data cannot be separated from the national development that the Indonesian government has carried out on an ongoing basis (Caraka \& Yasin, 2017; Philpott, 2018).

The importance of national development is quite reasonable when it is related to governance, where the objectives of development can be achieved if the government in the state administration is always clean, free of corruption, collusion, and nepotism. This was confirmed by the issuance of TAP MPR RI No. XI / MPR / 1998 concerning the implementation of a clean, free state of corruption, collusion, and nepotism in which there is a principle of accountability. Since the monetary crisis that hit Indonesia in 1997 and the reform era rolled along with the implementation of post-regional autonomy (Reback, 2008; Swinburn et al., 2015). Reform in 1998, there has been a significant change in the implementation of local governance in Indonesia. Presidential Instruction of the 
Republic of Indonesia Number 7 of 1999 concerning Performance Accountability of Government Agencies. In Presidential Instruction No. 7/1999, it is stated that in order to improve further the implementation of a more efficient, effective, clean, and responsible government, it is necessary to prepare a performance accountability report for government agencies so that the ability of government organizations can be identified in achieving the vision, mission, and objectives that have been set. Since the enactment of Presidential Regulation Number 29 of 2014 concerning SAKIP and Permen PAN RB Number 53 of 2014 concerning technical guidelines for performance agreements, performance appraisals, and review procedures for Government Agency Performance Reports, the reporting term from the original Government Agency Performance Accountability Report (LAKIP) has changed to Government Agency Performance Reports (LAMPKIN), in which it states that the implementation of SAKIP is a system for the accountability of government agencies (Ministries/Institutions, Regional Governments, and Work Units), is a systematic series of various activities, tools, and procedures designed to determine and measure, collecting data, classifying, summarizing, and reporting performance in government agencies. The city of Kediri is a city with a brand image of the service city, which is defined as a city of service and the winner of the 2019 SAKIP Award Making Changes Making History, Monday (27/1/2020) at Inaya Putri Bali, which was given directly by the Deputy for Bureaucratic Reform, Apparatus Accountability and Monitoring of the Ministry of National Education. Muhammad Yusuf Ateh to Mayor of Kediri Abdullah Abu Bakar for his achievements in the Government Agency Performance Accountability System (SAKIP) with the predicate BB, because it is assessed that the results of the evaluation are capable of performing, have a work culture with heart, and can make efficiency in the use of effective budgets that have a direct impact on society. In implementing SAKIP at the Kediri City Health Office, there are many problems faced, and solutions must be found immediately so that the Agency's Performance Accountability can be continuously improved and improved in order to be able to realize good governance in the Kediri City Health Office sustainably.

\section{Literature review}

Policy Implementation Implementation is the provision of means to implement a policy, and it can have an impact/effect on certain things (Widodo, 2021; Jupir, 2013; Herwiyanti et al., 2017). Widodo, (2021) explain that policy implementation emphasizes actions, both those carried out by the government and private individuals, that are directed to achieve the goals that have been set in a previous policy decision. Policy implementation is part of a series of public policy processes. The policy process is a series of interdependent stages arranged according to time sequence, agenda-setting, policy formulation, policy adoption, and policy assessment.

The process that needs to be emphasized here is that the policy implementation stage will not start until goals and suggestions are set or identified by decisions. Policy. Thus, the implementation stage occurs only after the law is enacted and funds are provided to finance the implementation of the policy Hutahayan (2019). George Edward III's theory consists of; communication, HR, disposition and bureaucratic Structure Public Accountability. According to Santoso \& Pambelum (2008), public accountability is the obligation of the agent to provide accountability, present, report, and disclose all activities and activities that are their responsibility to the principal, who has the right and authority to hold accountability. Elements of the embodiment of good governance that are being carried out in Indonesia, because according to McCall \& Dunn (2012) accountability is the key to the concept of good governance, supporting this it is necessary to develop and implement a system of accountability that is precise, clear, and measurable, and takes place in an efficient, effective, clean and efficient manner. Responsible and free from collusion, corruption, and nepotism (Bracci, 2009; Figlio \& Winicki, 2005).

Romzek \& Dubnick (1998) define accountability as a relationship between individuals or agents to show performance to the trustee. According to Bastian (2019) accountability can be defined as the responsibility for managing resources and implementing the policies entrusted to the reporting entity to achieve the objectives set periodically. According to Platonova (2013) accountability is the obligation of individuals or authorities entrusted with managing public resources and related to them to be able to answer matters concerning their responsibilities. It can be concluded that in the context of government organizations, public accountability is the provision of information and disclosure of government financial activities and performance to parties with interest in the report. The government must be able to become the subject of providing information in the context of fulfilling public rights; in other words, public accountability requires public sector institutions to be more able to provide responsibility both horizontally and vertically (Figlio \& Loeb, 2011; Nofianti \& Suseno, 2014). That accountability is an obligation that is the government's responsibility as an agent to society as a principal to provide accountability, presentation, and reporting, disclosure of all activities and activities for which he is responsible. The government acts as an actor providing information to fulfill public rights, namely the right to know, the right to be informed, and the 
right to be heard by their aspirations and accountability are the logical consequences of the relational model between Principal and Agent. The types of public accountability consist of two types, according to Kamaroellah (2017) namely; vertical accountability vertically, which is the accountability of the central government and the central government to the MPR, horizontal accountability horizontally and is accountability to the broader community or the public.

\section{Research methods}

The method used in this research is the descriptive research method with a qualitative approach. According to Leavy (2017) research using the descriptive method intends to create awareness systematically, factually, and accurately regarding the facts and characteristics of a particular population. Based on the above understanding, this research is directed to provide symptoms, facts, or events systematically and accurately regarding the nature of the population and analyze the truth based on the data obtained. This research uses qualitative research. According to Silverman (2020) qualitative research intends to understand the phenomena experienced by research subjects such as behavior, perception, motivation, action, and others holistically and utilizing descriptions in words and language in a particular context utilizing various natural methods. According to Raskind et al. (2019) most qualitative research starts with a vague or loosely defined topic. Specific topics emerged slowly throughout the study and may change direction based on new evidence. Lawrence (2010) calls qualitative research a new research method because of its recent popularity; it is called the postpositivist method because it is based on postpositivism. Research sites this research was conducted at the Kediri City. Research Informants Qualitative research is not intended to make generalizations from the results of the research. Therefore, in qualitative research, there is no known population and sample. In this study, researchers used purposive sampling.

\section{Results and Discussion}

Implementation of Performance Accountability for Government Agencies (SAKIP) at the Kediri City Health Office The Government Agency Performance Accountability Report (LAKIP) was changed to the Government Agency Performance Report (LKjIP). According to Presidential Regulation Number 29 of 2014 concerning SAKIP and Permen PAN RB Number 53 of 2014 concerning Technical Guidelines on Performance Agreements, Performance Appraisals, and Procedures for Reviewing Performance Reports Government Agencies, the elements of SAKIP consist of; Strategic Plan/Rienstra, Performance Agreement, Performance Measurement, Performance data management, Performance Reporting and Review and evaluation of performance.

The SAKIP period in 2019 follows the Kediri City RPJMD for the 2014-2019 period, while in 2020, it follows the Kediri City RPJMD for the 2020-2024 period. SKIP for the 2020-2024 period is the continuation of the implementation of SAKIP for the 2014-2019 period, where in the 2014-2019 period, there is more emphasis on efforts to improve both health service facilities and the degree of public health. In the 2020-2024 period, the RPJMD Kota Kediri emphasizes how the results obtained from the efforts for the 2014-2019 period by improving public health and access services that are felt to be lacking in the previous period.

In 2020, some programs were constrained in implementing their activities and are diverted to resolve the Corona19 Virus Outbreak by maximizing the improvement of public health with the priority of overcoming the Corona-19 Virus Outbreak so that they do not want any changes related to the performance agreement. Based on the results of the evaluation of the performance of the Kediri City Health Office, it can be concluded that the average performance achievement of the 2019 Health Office is $80.5 \%$, which is classified as below $100 \%$, which means that it has not been achieved. In 2020, the average achievement of this target performance indicator was $80.79 \%$ with the unattainable category. In its implementation, it is following the implementation of the policy, according to the existing regulations, what needs to be improved is the regular socialization, coordination and monitoring and evaluation.

Problems faced in implementing the Government Agency Performance Accountability System (SAKIP) at the Kediri City Health Office. Researcher's findings related to problems faced in the SAKIP implementation process in terms of LKjIP were obtained from collecting documents related to SAKIP, the results were: Problems Included 2019 ; 1) The policies for implementing programs and activities between the fields and program managers at the Kediri City Health Office have not all synergized. 2) Not all programs at the Kediri City Health Office work in synergy. 3) Limited program management staff at the Health Office, so that planning and implementing activities in order to achieve achievement. Problems Included 2020;1) Existing health service infrastructure and medical and non-medical equipment at puskesmas, puskesmas auxiliary, and post health center still need to be improved in 
quantity and quality. 2) The independence of the community in the health sector by habituating community behavior in the health sector with the habit of getting Clean and Healthy Behavior (PHBS) and the management of healthy public places and a healthy environment through the Healthy Community Movement (GERMAS) needs to be improved, including the problem of Covid. 3) Still found toddlers with malnutrition and malnutrition in society. 4) Not yet optimal achievement of the goals of Universal Health Coverage (UHC) was essential.

Table 1

The problems faced in the process of implementing resulted SAKIP

\begin{tabular}{ll}
\hline \multicolumn{1}{c}{ Causative factor } & \multicolumn{1}{c}{ Problems } \\
\hline Communication & - a difference of interpretation in the implementation \\
& process SAKIP \\
& - Inadequate socialization in the implementation process \\
& of SAKIP \\
& - lack of coordination in the process of implementing \\
& SAKIP \\
& - the existing human resources in terms of quality still \\
& have a variety of abilities. \\
Human resources & - \\
Facilities and infrastructure & - the division of labor policy is not clear because there is \\
Funding & no SOP \\
Disposition & - there is no periodic monitoring and evaluation; there is \\
& no incentive \\
& - There is no SOP related to SAKIP
\end{tabular}

The solution to Problems in Implementing SAKIP in the Health Office of the City of Kediri The solution to the problems faced in the case of LKjIP was obtained from collecting documents related to SAKIP, the results were:

The 2019 year; 1) Synergy in formulating and implementing programs and activities at the level of Kediri City, the Health Officer, and the Community Health Center must be further improved and services to the community by enforcing regular health service procedures and public service standards at the Puskesmas. 2) Increase the professionalism of health workers in the UPTD who directly provide services to the community by enforcing regular health service procedures and public service standards at the Puskesmas. 3) Optimization of all resources owned by the Health Office and its staff within provide services regarding the feasibility and quality of resources so that health services can be easily accessed.

The 2020 year; 1) Improving program performance by optimizing the roles of each officer, health and improving health regulation. 2) changes to the performance evaluation system based on analysis, policy \& implementation, coaching, and increasing the quality and quantity of Human Resources, infrastructure, and facilities. 3) Increasing public and private participation/participation in the health sector through health promotion, strengthening crosssector coordination. 4) improving health information systems and improving health regulations.

Table 2

Solutions to problems encountered in the SAKIP implementation process include

\begin{tabular}{ll}
\hline \multicolumn{1}{c}{ Factors Cause } & \multicolumn{1}{c}{ Solution } \\
\hline Communication & Making a joint commitment is used to remind each \\
& other that there is a shared obligation and responsibility \\
& to carry out SAKIP \\
& - Increased socialization and coordination so that there is \\
& clear and consistent communication about the direction, \\
& goals, content, and objectives to be achieved in this \\
& matter is the SAKIP implementation process. \\
& - Policies related to socialization and training must be \\
Human resources & budgeted for and carried out regularly by the Kediri \\
& City Health Office in order to improve the quality of \\
\hline
\end{tabular}


Facilities and infrastructure

Funding

Disposition

Organizational Structure human resources

- Immediately make a policy for the implementation of SAKIP SOP

- Policies related to the making of SAKIP SOP

\section{Conclusions}

The implementation of SAKIP, is following government regulations and the six indicators of the existing LKjIP elements, which need to be improved, namely regular socialization, coordination and monitoring and evaluation 2014-2019 carries out its obligations by reporting the results of SAKIP and presentation by the Head of the Kediri City Health Office every year. 2020-2024 makes innovations by providing web links to access and then participate in viewing, monitoring, and reviewing performance results to realize good governance. Based on the policy elements, everything has been implemented quite well; there needs to be an increase in communication, human resources, disposition, and organizational structure. Of the nine indicators that affect good governance that need to be improved lies in community participation according to the role of SAKIP as a performance accountability tool. The effort that needs to be made by the Kediri City Health Office is to make public service announcements related to the implementation of SAKIP.

Acknowledgments

All authors are also grateful to all colleagues for their support in the form of initial ideas and feedback from the beginning to the final stage of this paper. Do not miss our thanks and appreciation to the Directorate of Higher Education for funding support to complete this study following the planning with very satisfying results.

\section{References}

Bastian, I. (2019). Lingkup Akuntansi Sektor Publik. Lingkup Akuntansi Sektor Publik.

Caraka, R. E., \& Yasin, H. (2017). Spatial Data Panel. Wade Group.

Figlio, D. N., \& Winicki, J. (2005). Food for thought: the effects of school accountability plans on school nutrition. Journal of public Economics, 89(2-3), 381-394. https://doi.org/10.1016/j.jpubeco.2003.10.007

Figlio, D., \& Loeb, S. (2011). School accountability. Handbook of the Economics of Education, 3, $383-421$. https://doi.org/10.1016/B978-0-444-53429-3.00008-9

Herwiyanti, E., Sukirman, S., \& Aziz, F. S. (2017). Analisis Implementasi Akuntansi Berbasis Akrual pada Bracci, E. (2009). Autonomy, responsibility and accountability in the Italian school system. Critical perspectives on accounting, 20(3), 293-312. https://doi.org/10.1016/j.cpa.2008.09.001

Inspektorat Jenderal Kementerian Keuangan. Jurnal Akuntansi Dan Keuangan, 19(1), 13-23.

Hutahayan, J. F. (2019). Faktor Pengaruh Kebijakan Keterbukaan Informasi Dan Kinerja Pelayanan Publik. Yogyakarta.

Jupir, M. M. (2013). Implementasi kebijakan pariwisata berbasis kearifan lokal (studi di Kabupaten Manggarai Barat). Journal of Indonesian Tourism and Development Studies, 1(1), 28-38.

Kamaroellah, R. A. (2017). Analisis Tingkat Kemampuan Keuangan Daerah dalam Mendukung Pelaksanaan Otonomi Daerah. NUANSA: Jurnal Penelitian Ilmu Sosial Dan Keagamaan Islam, 14(1), 123-138.

Lawrence, M. (2010). Young adults' experience of stroke: A qualitative review of the literature. British Journal of Nursing, 19(4), 241-248.

Leavy, P. (2017). Research design: Quantitative, qualitative, mixed methods, arts-based, and community-based participatory research approaches.

McCall, M. K., \& Dunn, C. E. (2012). Geo-information tools for participatory spatial planning: Fulfilling the criteria for 'good'governance? Geoforum, 43(1), 81-94.

Nofianti, L., \& Suseno, N. S. (2014). Factors affecting implementation of good government governance (GGG) and their implications towards performance accountability. Procedia-Social and Behavioral Sciences, 164, 98-105. https://doi.org/10.1016/j.sbspro.2014.11.056

Philpott, S. (2018). This stillness, this lack of incident: Making conflict visible in West Papua. Critical Asian Studies, $50(2), 259-277$.

Platonova, E. (2013). Corporate social responsibility from an Islamic moral economy perspective: A literature survey. Afro Eurasian Studies, 2(1-2), 272-297. 
Raskind, I. G., Shelton, R. C., Comeau, D. L., Cooper, H. L., Griffith, D. M., \& Kegler, M. C. (2019). A review of qualitative data analysis practices in health education and health behavior research. Health Education \& Behavior, 46(1), 32-39.

Reback, R. (2008). Teaching to the rating: School accountability and the distribution of student achievement. Journal of public economics, 92(5-6), 1394-1415. https://doi.org/10.1016/j.jpubeco.2007.05.003

Romzek, B. S., \& Dubnick, M. J. (1998). Accountability.

Santoso, U., \& Pambelum, Y. J. (2008). Pengaruh penerapan akuntansi sektor publik terhadap akuntabilitas kinerja instansi pemerintah dalam mencegah fraud. Jurnal Administrasi Bisnis, 4(1).

Swinburn, B., Kraak, V., Rutter, H., Vandevijvere, S., Lobstein, T., Sacks, G., .. \& Magnusson, R. (2015). Strengthening of accountability systems to create healthy food environments and reduce global obesity. The Lancet, 385(9986), 2534-2545. https://doi.org/10.1016/S0140-6736(14)61747-5

Silverman, D. (2020). Qualitative research. Sage Publications Limited.

Widodo, J. (2021). Analisis kebijakan publik: Konsep dan aplikasi analisis proses kebijakan publik. Media Nusa Creative (MNC Publishing). 